
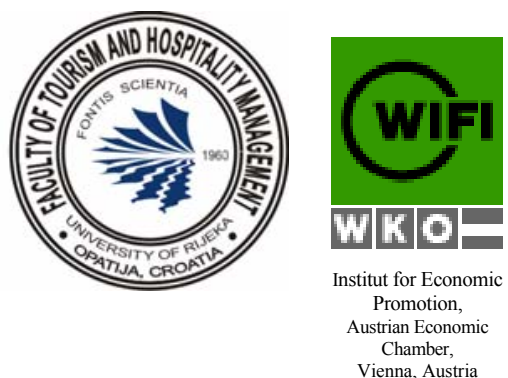

Vienna, Austria

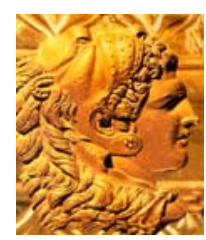

T.E.I. Thessalonik

Greece

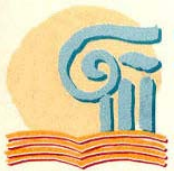

Department of Tourism Management
UDC 338.486(498)

Rewiev Received: 25.09.2008

\title{
GREEN MARKETING: A NEW CHALLENGE FOR ROMANIAN ORGANIZATIONS
}

\author{
Andreea Muntean \\ Fillimon Stremtan \\ “ $1{ }^{\text {st }}$ December 1918" University of Alba Iulia, Romania ${ }^{1}$
}

\begin{abstract}
Eco-innovation and green marketing are the new weapons for the progressive companies in tourism. Environmental improvements can enhance marketability, improve performance, and represent a potent source of innovation.

From an organizational standpoint, green marketing means to integrate environmental considerations into all aspects of new touristic product development and marketing.

In actual conditions, Romanian touristic companies should prepare to include ecological impact as a part of its marketing strategy. Given current environmental imperatives, they represent the next important stage in corporate environmental management and hence, corporate reputation management. Being "green" is not just a fad, and Romanian companies will have to join the likes of other international firms in preparing marketing strategies to support their sustainability policies. Companies that can prove to consumers and business partners that they are serious about their environmental impact will reinforce their branding.

This paper tries to underline how important is for a touristic company to develop sustainable eco - marketing strategy and it proposes some solutions about what Romanian companies should do.
\end{abstract}

Keywords: green marketing, eco-innovation, environmental improvements, social responsibility.

\footnotetext{
${ }^{1}$ Andreea Muntean, Lecturer, Filimon Stremtan, Ph.D. Full Professor Faculty of Sciences, "1 1 st December
} 1918" University of Alba Iulia, Romania 
Tourism and Hospitality Management, Vol. 14, No. 2, pp. 343-348, 2008

A. Muntean, F. Stremtan: GREEN-MARKETING: A NEW CHALLENGE FOR ROMANIAN ...

\section{INTRODUCTION}

Dumitru C., in her book "Ecologic Management and Marketing. A strategic perspective" defines environmental marketing as "the process which leads to sustainable changes from an ecological perspective, through the creation of new products and services and which, through a coherently administration of distribution, communication and public relations, allows the satisfaction of consumer needs and the claiming of the objectives which satisfies firm's and society priorities".

\section{GREEN MARKETING: A NEW CHALLENGE}

According with the same author, there are three factors which are affecting the marketing focus on environmental conditions: the emergency of a segment of "green consumers", the pressure exerted by the public authorities and by the non governmental green organizations and the increasing of organizations' social responsibility.

Innovator organizations would have to find more and more collaborations forms with "green groups", which can be perceived by the consumers, such as: obtaining the agreement for using information about the good relationships with such groups in the communication message, the patronage of such groups as a form of social responsibility, product certification by a green organization, collaboration with green groups for solving the environmental problems related with firm's activity.

Marketing theory approaches the concept of "green marketing" by focusing on the relationship with consumers, with public authorities and with society. In the modern society, consumers want from the touristic services, beyond the satisfaction of their primary needs, a high level of life quality. This new approach brings a third partner in the relation "Firm - Customer" and this partner is the Society.

A lot of social factors had determined the increase of consumers preoccupations for the environment, such as: in the latest times, environment problems have affected the population majority; the consumer movement against globalization has extended in the same time with the sustainable development theory; young people learn about the environment in the first years of study; a new generation of teenagers has joined an educational system based on "nature returning".

These social factors has contributed to the formation of a new tourist type - the ecologic tourist. The behavior of this consumer is oriented through the recycling and saving and also demonstrates a good perception and acknowledgment of the environment damages and a real preoccupation for its natural resources.

In actual conditions, Romanian touristic companies should prepare to include ecological impact as a part of their marketing strategy. Given current environmental imperatives, they represent the next important stage in corporate environmental management and hence, corporate reputation management. Being "green" is not just a fad, and Romanian touristic companies will have to join the likes of Ford, General 
Tourism and Hospitality Management, Vol. 14, No. 2, pp. 343-348, 2008

A. Muntean, F. Stremtan: GREEN-MARKETING: A NEW CHALLENGE FOR ROMANIAN ...

Electric or Toyota in preparing marketing strategies to support their sustainability policies. Companies that can prove to consumers and business partners that they are serious about their environmental impact will reinforce their branding.

Results of a study conducted by M.I. Roşca demonstrate that there is a lack of interest regarding the ecological features or just a show of interest in behalf of the Romanian touristic companies [5]. From a total sample of 177 Romanian touristic firms, less than $25 \%$ are informed about the concept of "green marketing". On a differential semantic scale, the degree in which companies applied principles of "green marketing" had obtained a score of 1.98 [5].

Starting from 1992 initiated programme, at the European Union level, which sustains the implementation of 17 "tourism and environment" pilot projects, in the entire Europe, within the activity programme derived from the reform strategy that our country has, a notable place is held by the problems concerning the development and promotion of rural tourism.

Romanian Tourism Minister paid a special attention to the improvement of the legislative frame adequate for stimulation, development and harmonization of the rural tourism with the laws from the European Union Countries. Practicing a "green" tourism needs the implication of the decisional factors through economic development policy, through juridical, legislative, financial-banking, local administrations regulations.

In our country there are numerous villages that have convenient terms when it comes to practicing ecotourism, but their poor capitalization determined the resort minister to consider the agro-tourism as a real opportunity for local economies and, thus, for the rural development as a whole.

The option for new tourism ways results also, from the analysis of the negative aspects of the real situation from hotels / restaurants industry, that is:

- the placing of hotel units or restaurants, especially those from large urban agglomerations, in areas with a lot of dust, noise, smoke and gases from the exhaust of the cars that drive through these areas;

- the design of these units that must be harmonized with the new environmental demands, re-thinking the ventilation and heating systems, the airtight of the windows and entering ways of the unwanted temperatures (draught, cold or heat);

- the inappropriate usage of water supplies provided by the municipal or city networks, in the chronic lack of the drinking water in many places, the exorbitant increase of the supplying price but also the huge waste that happens when taps are out of order etc.;

- great power consumptions when are used old equipments and technologies burners and boilers with big consumption and low output, that pollute the environment with carbon dioxide issue and noxious sulphur derivate; 
Tourism and Hospitality Management, Vol. 14, No. 2, pp. 343-348, 2008

A. Muntean, F. Stremtan: GREEN-MARKETING: A NEW CHALLENGE FOR ROMANIAN ...

- the usage of some "un-ecological" bleachers and detergents that affects the air and water by their draining into the sewer or strait into the rivers or sea, without treating the used waters and without reducing the negative impact on the environment;

- $\quad$ non sorting the domestic waste before it is thrown to containers, this leading to the evacuation of waste with a poisoning environment increasing risk;

- the lack of a real support industry for recycling the huge quantity of waste that can be re-used, the lack of facilitation given to those who initiated and developed active sorting, collecting, and even processing / recycling wastes policies;

- the lack of some coherent environment protection programs, including the tourist environment, been known the fact that the tourism "swallows" all the undone and negative situations, reflected in the consumer's "appetite" for tourism.

The proposed solutions are, mostly, case studies and notable realizations from countries with a developed tourism, all based on long experiences and successful accomplishments:

- intermediary filters made from stainless steel that retain sands / silt that came on the distribution network;

- $\quad$ filters that treat and ionize the water;

- magneto-ceramic filters that reduce the hardness of the water and "break" the limestone and magnesium agglomeration which form deposits on pipes, reducing the pressure in an unjustified way and "eating" the pipes, without destroying the calcium and magnesium from the water;

- filters with active charcoal or with multiple crystal layers, which retain the bad taste and smell of chlorinate or muddy (dirty) water, but also the eventual fine particles unstopped by the other intermediary filters.

All those types of filters, made by well known firms, can also be bought from the Romanian market. Using this kind of filters, in combination with biodegradable detergents used in dishwashers or laundries increases the life rate of the water's interior circuit installations, of the equipments and installations; the waters will be cleaner and less noxious.

One of the extremely important chapters when it comes to exceeding and solving those problems is represented by communication. Communication can be presented on two fundamental aspects:

- the unit's staff, the one that can and must apply all modern ecological management methods of the hotels / restaurants environment, saving consumed resources, reducing the waste etc. and, finally, to bring the client's satisfaction;

- the client, the addressee, and the final receiver. 
Tourism and Hospitality Management, Vol. 14, No. 2, pp. 343-348, 2008

A. Muntean, F. Stremtan: GREEN-MARKETING: A NEW CHALLENGE FOR ROMANIAN ...

In order to obtain those issues, some procedures are needed in both ways:

- on one hand the staff must be periodical and solidly trained about the "ecologic" tasks and cooperation with other partners and clients;

- on the other hand, communicating towards the clients all environmental impact measures, that should convince them to appreciate those efforts, to adhere to those measures and to become an active part in the introduction and development of ecological programs promoted by hotels and restaurants.

As an active part of the communicational process, the client must understand:

- why the "green" road was chosen;

- how water, energy, detergents can be saved;

- how, certain resources, can be saved without reducing the comfort;

- how can they contribute to funds collecting concerning certain simulative actions (the funds can be obtained from selling different recyclable waste).

The communication with clients and staff's training are considered the "hidden" arms of every manager in the success of the ecological management of the hotels, restaurants and professional formation.

The evolution of the economy and of the Romanian society can be conceived in trend with the minimal environment's protection requests, demand that is also available for tourism activity. The legislation in force compels the tourism, hotels and restaurants operators to be patented through environment agreement and to strictly respect the environment protection laws, either by taking punitive measures (penalties, redrawing the right / license to function for polluting, the lack of order) or by applying some prohibitive prices for energy, fuels and water, in the context of a free market.

These measures come to alert the operators in both ways:

- on one hand by applying strictly the legal norms for conserving the environment, otherwise they will be punished by law;

- on the other hand, by applying some active policies for environment protection, to save important resources, to be attractive on local, national and international tourism market.

\section{CONCLUSION}

In conclusion, this paper tried to underline how important is for a company to develop sustainable eco - marketing strategy and it proposes some solutions about what touristic firms should do, like follows:

- Romanian touristic companies should ensure that eco-innovative efforts are communicated in all corporate environmental and sustainability reports, as well as responses to questionnaires from customers and socially responsible investors, and in-house organs;

- Romanian touristic organizations should make a public commitment to 
Tourism and Hospitality Management, Vol. 14, No. 2, pp. 343-348, 2008

A. Muntean, F. Stremtan: GREEN-MARKETING: A NEW CHALLENGE FOR ROMANIAN ...

develop more eco-innovative products. In this way, the ideal goal is zero emissions, zero waste, zero environmental impact. A zero environmental impact requires a commitment to continuous innovation. This will ensure that companies will stay ahead of the environmental curve and keep internal stake holders allied for maximum support;

- Romanian touristic companies should ensure that commitments emanate from the highest level of the company;

- Romanian touristic companies should educate their consumers about what they personally can do help. This includes promoting responsible consumption of products by consumers. Consumers are eager recipients of new information about how their product purchase and behavior can help the environment.

\section{REFERENCES}

Dumitru C.: Management si marketing ecologic - o noua abordare strategica. Editura Tehnopress. Iasi, 2003. Cramer, J.: Environmental Management: From 'Fit' To 'Stretch'. Business Strategy and the Environment, Vol. 7, 1998, no. 4, p. 162-172.

Ottman, J.: Green Marketing: Opportunity for Innovation. MacGraw Hill. New York, 1998.

Peattie, K.: Environmental Marketing Management. Meeting the Green Challenge, London, 1995.

Roşca, M.I.: Cercetarea impactului marketingului ecologic in intreprinderile din Romania. Revista Romana de Marketing, nr. 1, 2006

Balaure V (coord.).: Marketing. Editura Uranus,.Bucuresti, 2003. 